\title{
Sensory Properties and Consumer Liking of Buffalo Stracchino Cheese
}

\author{
M. Di Cairano ${ }^{1}$, C. Pacelli ${ }^{1}$, A. Bragaglio ${ }^{2}$, F. Napolitano $0^{1, *}$ and A. Braghieri ${ }^{1}$ \\ ${ }^{1}$ School of Agricultural, Forestry, Food and Environmental Sciences, University of Basilicata, Via dell'Ateneo \\ Lucano 10, 85100 Potenza, Italy \\ ${ }^{2}$ Department of Veterinary Medicine, University of Bari Aldo Moro, S.P. per Casamassima km. 3, 70010 \\ Valenzano, BA, Italy
}

\begin{abstract}
The present study aims to characterize buffalo Stracchino cheese (BS) from a sensory point of view and verify how much consumers like it compared with the standard Stracchino cheese obtained from cow milk (CS). Nine panelists specifically trained to evaluate Stracchino cheese were used to conduct a quantitative descriptive sensory analysis, whereas 80 untrained consumers balanced for gender participated in the hedonic consumer test. Stracchino appearance was affected by milk type with higher intensities perceived for BS in terms of whiteness $(P<0.0001)$ and shininess $(P<0.001)$. As to taste and texture, BS showed higher sourness and oiliness intensities than CS, respectively $(\mathrm{P}<0.0001)$. Milk type did not affect the overall liking or the liking in terms of taste/flavor, texture, and appearance, but consumers rated both products at scores well above the neutral point. In addition, the liking expressed in blind conditions (i.e., without information on the milk type) was significantly lower as compared with the liking elicited by the expectations (i.e., based only on the information on the milk type) $(\mathrm{P}<0.05$ and $\mathrm{P}<0.10$, for $\mathrm{CS}$ and $\mathrm{BS}$, respectively). We conclude that the good eating quality of buffalo Stracchino cheese as assessed by the consumer panel and the lack of differences between CS and BS in terms of a consumer may anticipate a possible good positioning of this novel product in the market of fresh cheese.
\end{abstract}

Keywords: Buffalo, Stracchino cheese, Sensory profile, Consumer liking.

\section{INTRODUCTION}

The number of buffalo cows and buffalo milk produced worldwide have been steadily increasing since 1960 [1]. However, in the countries where this species is most common (e.g., India, Pakistan, Nepal, Egypt), the same trend can be observed for other dairy species, and the proportion of buffalo milk did not increase or even decrease over the same period. Conversely, in Italy, the proportion of buffalo milk increased compared with that produced by other dairy species in the same period [1]. Zicarelli [2] explained this trend based on the high market shares of buffalo mozzarella cheese driving milk production and buffalo population consistency.

Mozzarella is a typical dairy Italian product currently also consumed in other European and American countries. However, (due to a progressive saturation) the mozzarella cheese market is becoming increasingly competitive [3]. Although the situation for buffalo mozzarella cheese is different, with market shares constantly growing since the mid-eighties [2], a possible future saturation may be expected. In addition, the mozzarella cheese market is very seasonal, with peaks of consumption in spring-summer and very low

*Address correspondence to this author at the School of Agricultural, Forestry, Food and Environmental Sciences, University of Basilicata,, Via dell'Ateneo Lucano 10, 85100 Potenza, Italy; Tel: +39 0971205078 ;

E-mail: fabio.napolitano@unibas.it levels of purchase in winter [4]. Conversely, the reproductive physiology of these animals determines the concentration of the parturitions in autumn, as buffaloes show a higher reproductive activity with a decreasing number of daylight hours corresponding to the end of summer [4]. Therefore, after 10 monthpregnancy, lactation starts, and the peaks of production occur in winter. In Italy, some farms tackle this problem by applying an out of breeding mating strategy where animals are not allowed to mate in October-January to concentrate milk production in spring-summer. However, the mismatch between the mozzarella cheese offer and the consumer demand may represent a serious commercial problem worsened by the product's short shelf-life [5].

Stracchino cheese is another typical Italian product traditionally made out of cow milk, which shares the attribute of freshness with mozzarella cheese. Freshness is a positive aspect of food that is very well received by consumers [6]. However, the process and product characteristics inducing freshness in mozzarella cheeses also imply high moisture contents (more than 50\%), making mozzarella cheese more perishable than other cheeses with similar moisture content but made out of pasteurized milk, such as stracchino cheese [7].

Although process characteristics play a central role in affecting the sensory profile of cheese, the effect of 
different animal breeds or species may also change the sensory properties of the final product, particularly in the case of fresh cheeses [8]. Quantitative descriptive sensory analysis (QDA) is the most appropriate tool for detecting sensory differences between products [9]. However, subtle changes in the sensory profile, albeit detectable by a trained sensory panel such as the one used in the QDA, maybe not be perceived by untrained consumers [10]. Therefore, the acceptability of a novel product should be tested on a large number of stracchino regular eaters.

The possible need for product differentiation in the near future and the necessity to overcome the mismatch between the offer and demand of mozzarella cheese may be tackled by introducing a novel product to be used for the transformation of buffalo milk, such as Stracchino cheese, whose market is not seasonal. In addition, the shelf-life is longer than that of mozzarella, which may facilitate the commercialization of this product.

However, little is known about the sensory properties and consumer liking of Stracchino cheese made out of buffalo milk. Therefore, the present study aims to characterize this novel product from a sensory point of view and verify how much consumers like it compared with the standard Stracchino cheese obtained by using cow milk.

\section{MATERIALS AND METHODS}

\section{Products}

The cheese-making procedure followed the steps traditionally used for stracchino cheese [7]. Briefly, milk was pasteurized at $72-75^{\circ} \mathrm{C}$ for 15 seconds. Then, in multipurpose vats at a temperature of $37-40^{\circ} \mathrm{C}$, milk enzymes, and liquid calf rennet were added to the milk and left to coagulate. Then the curd was broken up mechanically into grains the size of a walnut and kept slightly shaken for half an hour before being poured into the cheese moulds. Here the curd was left to mature at $25-30^{\circ} \mathrm{C}$ for $3-4$ hours, at high humidity levels, so that rind cannot form on the curd, which would slow down the draining off of the whey. After the drying-out phase and having obtained optimal acidity, the moulds were plunged into a concentrated brine solution at $15^{\circ} \mathrm{C}$ for 2 hours, where the paste cooled down and absorbed the necessary amount of salt. This was followed by a very short ageing period (7-10 days, in cells at $4^{\circ} \mathrm{C}$ with a humidity of $90 \%$ ). This procedure was applied both to bovine milk to produce cow stracchino cheese (CS) and to buffalo milk for the production of buffalo stracchino cheese (BC).

\section{Sensory Analyses}

Procedures involving consumers were conducted following the 1964 Helsinki declaration and its later amendments. Written informed consent was obtained from all the consumers participating in the study. In addition, we followed the Regulation (EU) 2016/679 of the European Parliament and of the Council of 27 April 2016 on the protection of natural persons concerning the processing of personal data and the free movement of such data as our institution has a personal data management system that follows these standards.

\section{Quantitative Descriptive Analysis}

Sensory analysis was carried on both BS and CS samples. To conduct a quantitative descriptive analysis (QDA) [9], fifteen subjects were recruited by phone among regular eaters of stracchino cheese (defined as consuming the product at least once a month). According to ISO recommendations, nine panelists ( 7 females and 2 males, between 22 and 30 years of age) were selected [11]. For this purpose, the four basic tastes [12] and Sniffin' Sticks Identification Test [13] was used.

During preliminary sessions, the assessors were asked to taste stracchino cheese samples, and based on available literature [14], they tried to describe their taste, odour, flavour, appearance, and texture attributes. Then, under the guidance of the panel leader, they developed and agreed on a consensus list of attributes and their definitions (Table 1). Subsequently, assessors were trained for scale use [15]. QDA is based on a $100 \mathrm{~mm}$ unstructured intensity linear scale, with anchor points at each end $(0=a b s e n t$ and $100=$ very strong). Therefore, panellists were trained to identify the intensity ranges for low, medium, and high intensity with standard reference products specific to each identified attribute. During the panel training, at least two points of the scale were anchored to the reference material (Table 1). The performance of the panellists, in terms of repeatability, discrimination, and agreement, assessed by ANOVA, may be considered satisfactory when none of the judge $x$ product, judge $\mathrm{x}$ replication, and replication $\mathrm{x}$ product interactions are significant $(P>0.05)$.

QDA tests on experimental samples were performed at about $10.00 \mathrm{~h}$ in individual sensory booths [16] under red fluorescent lights to mask colour 
Table 1: List of Attributes and Definitions Used by the 9-Member Trained Panel for Stracchino Cheese Sensory Profiling

\begin{tabular}{|c|c|c|c|}
\hline Attribute & Low & High & Definition \\
\hline \multicolumn{4}{|l|}{ Appearance } \\
\hline Whiteness & Emmental cheese & Cream cheese & $\begin{array}{l}\text { Visual characteristic evaluated on the recently cut surface } \\
\text { that measures the intensity of the white; }\end{array}$ \\
\hline $\begin{array}{l}\text { Adhesiveness (to the } \\
\text { knife) }\end{array}$ & Scamorza cheese & Cream cheese & $\begin{array}{l}\text { Visual feature that measures the adherence of the cheese to } \\
\text { the knife through the degree of cleanliness of the surface } \\
\text { after cutting and the amount of product that remains } \\
\text { attached }\end{array}$ \\
\hline Shape stability & $\begin{array}{l}\text { Stracchino cheese at } \\
\text { room temperature }\end{array}$ & Stracchino cheese at $4^{\circ} \mathrm{C}$ & $\begin{array}{l}\text { Visual feature that measures the ability of the sample to } \\
\text { maintain its original shape without deforming over time }\end{array}$ \\
\hline \multicolumn{4}{|l|}{ Taste } \\
\hline Sourness & $\begin{array}{l}8 \mathrm{~mL} \text { of stock } \\
\text { solution }{ }^{2} / 100 \mathrm{~mL} \\
\text { solution }\end{array}$ & $\begin{array}{c}16 \mathrm{~mL} \text { of stock } \\
\text { solution }{ }^{1} / 100 \mathrm{~mL} \text { solution }\end{array}$ & Fundamental taste associated with citric acid \\
\hline Sweetness & $\begin{array}{l}8 \mathrm{~mL} \text { of stock } \\
\text { solution }{ }^{3} / 100 \mathrm{~mL} \\
\text { solution }\end{array}$ & $\begin{array}{l}20 \mathrm{~mL} \text { of stock } \\
\text { solution }{ }^{2} / 100 \mathrm{~mL} \text { solution }\end{array}$ & Fundamental taste associated with sucrose \\
\hline \multicolumn{4}{|l|}{ Odour/flavour } \\
\hline Milk & $\begin{array}{l}\text { Water and whole milk } \\
\text { solution }(50 / 50)\end{array}$ & Whole milk at $100 \%$ & Odour/Flavor arising from milk at room temperature \\
\hline Brewer's yeast & $\begin{array}{l}5 \mathrm{~g} \text { of brewer's yeast } \\
\text { in } 100 \mathrm{ml} \text { of water }\end{array}$ & $\begin{array}{l}16 \mathrm{~g} \text { of brewer's yeast in } \\
20 \mathrm{ml} \text { of water }\end{array}$ & $\begin{array}{c}\text { Odour/Flavor arising from brewer's yeast at room } \\
\text { temperature }\end{array}$ \\
\hline Yoghurt & $\begin{array}{l}\text { Water and plain whole } \\
\text { yoghurt solution } \\
(90 / 10)\end{array}$ & Plain whole yoghurt & $\begin{array}{l}\text { Odour/Flavor associated with plain whole yoghurt at room } \\
\text { temperature }\end{array}$ \\
\hline \multicolumn{4}{|l|}{ Texture } \\
\hline Oiliness & Ricotta cheese & Mascarpone cheese & Amount of oily/fatty feeling in the mouth during chewing \\
\hline Adhesiveness & Scamorza cheese & Cream cheese & $\begin{array}{l}\text { The degree to which the chewed sample sticks to the } \\
\text { surface of the mouth and teeth }\end{array}$ \\
\hline
\end{tabular}


differences in the samples, except during the evaluation of cheese appearance, when only white fluorescent lighting was used. In all tests, two cheese slices (15-20 g) of each sample were served in random order at a serving temperature of $13^{\circ} \mathrm{C}$ [17]: one slice was used for appearance attributes and the other for odour, flavour and texture features. Panellists were asked to eat a slice of apple between samples to restore the mouth's neutrality. They evaluated 4 replicates of each sample. Smart Sensory box (Smart Sensory Solutions Srl, Italy) generated sensory sessions and conducted the test.

\section{Consumer Test}

A total of 80 consumers, with an average age of 38 years and balanced for gender, participated in the test. Each participant evaluated the two samples, identified by a random three-digit code, in the same controlled sensory analysis laboratory. For each sample, consumers rated an overall liking and a liking according to the following sensory inputs: appearance, taste/flavour and texture, using a 9-point hedonic scale, where the 9 categories range from "dislike extremely" to "like extremely", with a central point (5) corresponding to "neither liked nor disliked" [18, 19]. They were encouraged to eat a slice of apple between samples to make the palate conditions similar for each sample. In addition, the effect of information about milk type (cow vs. buffalo milk) on consumer expectations (expected liking) was assessed using the same hedonic scale.

\section{Statistical Analyses}

To verify the performance of the panel, in terms of repeatability, data relating to the sensory profile were subjected to Variance Analysis (ANOVA), according to the GLM procedure [20], considering as factors the type of milk (2 levels), the judge (9 levels), the replication (4 levels) and related interactions.

A further ANOVA was performed on the sensory data, according to the MIXED procedure [20], considering the type of milk (2 levels), as a fixed factor, and the replication (4 levels) and the judge (9 levels), as random factors.

The ANOVA was also carried out on the overall liking scores and liking expressed for appearance, taste/flavour and texture, considering the type of milk as a factor. Furthermore, to verify the effect of the information on the liking of the products, a comparison was made between the data obtained in the blind phase (tasting in the consumer test without information) and those relating to the expected liking phase (liking expressed for the information received without tasting the actual product) by the Student's t-test (expected vs. blind).

\section{RESULTS AND DISCUSSION}

The preliminary ANOVA revealed no significant product $x$ replication or product $x$ assessor interactions, suggesting the efficacy of the training program and the adequacy of the reference frame used in this study, both allowing to reach high reliability of the panel (i.e., products were not evaluated differently in different replications or by different assessors).

Stracchino appearance was affected by milk type in terms of whiteness (mean \pm SE: $50.57 \pm 4.80$ vs. 21.87 $\pm 4.80, P<0.0001)$ and shininess $(60.35 \pm 4.24$ vs. $43.03 \pm 4.24, \quad P=0.0049$ ), with higher intensities perceived for BS. This may be due to the lack of $\beta$ carotene in buffalo milk. Buffalo milk has a distinctive white colour as the carotenoids are absent because they are converted into vitamin-A [21]. The concentrations of caseins in the milk also play a role with whiter appearance associated with higher casein contents [22]. Conversely, cow milk tends to be yellower due to the presence of $\beta$-carotene, which is less efficiently converted into vitamin-A [23]. Therefore, when cows graze on pasture, milk and cheese show a higher yellow intensity, which does not occur in buffaloes. The higher intensities of the attributes whiteness and shininess may favour the product's image in terms of freshness with possible positive effects on the positioning of BS in the market of fresh cheeses. In terms of appearance, the attribute spreadability was also affected by the milk type and scored at a higher intensity in CS than BS (24.25 \pm 2.96 vs. $13.12 \pm 2.96, \quad P=0.0094)$. It can be hypothesized that a higher content of casein in BS may have reduced the ability of the cheese to be spread in a thin and uniform layer.

Buffalo stracchino cheese showed higher sourness intensity $(68.21 \pm 2.74$ vs. $52.22 \pm 2.74, \mathrm{P}<0.0001)$ than cow stracchino cheese. This result can be attributed to buffalo milk being higher in fat, lactose, protein and minerals than cow milk, with a consequent higher capacity to be acidified [24, 25]. In addition, oiliness showed a higher intensity $(89.01 \pm 2.87$ vs. $62.10 \pm$ $2.87, \mathrm{P}<0.0001)$ in samples BS compared with CS, possibly due to the higher fat content of buffalo milk have affected cheese composition and texture. 


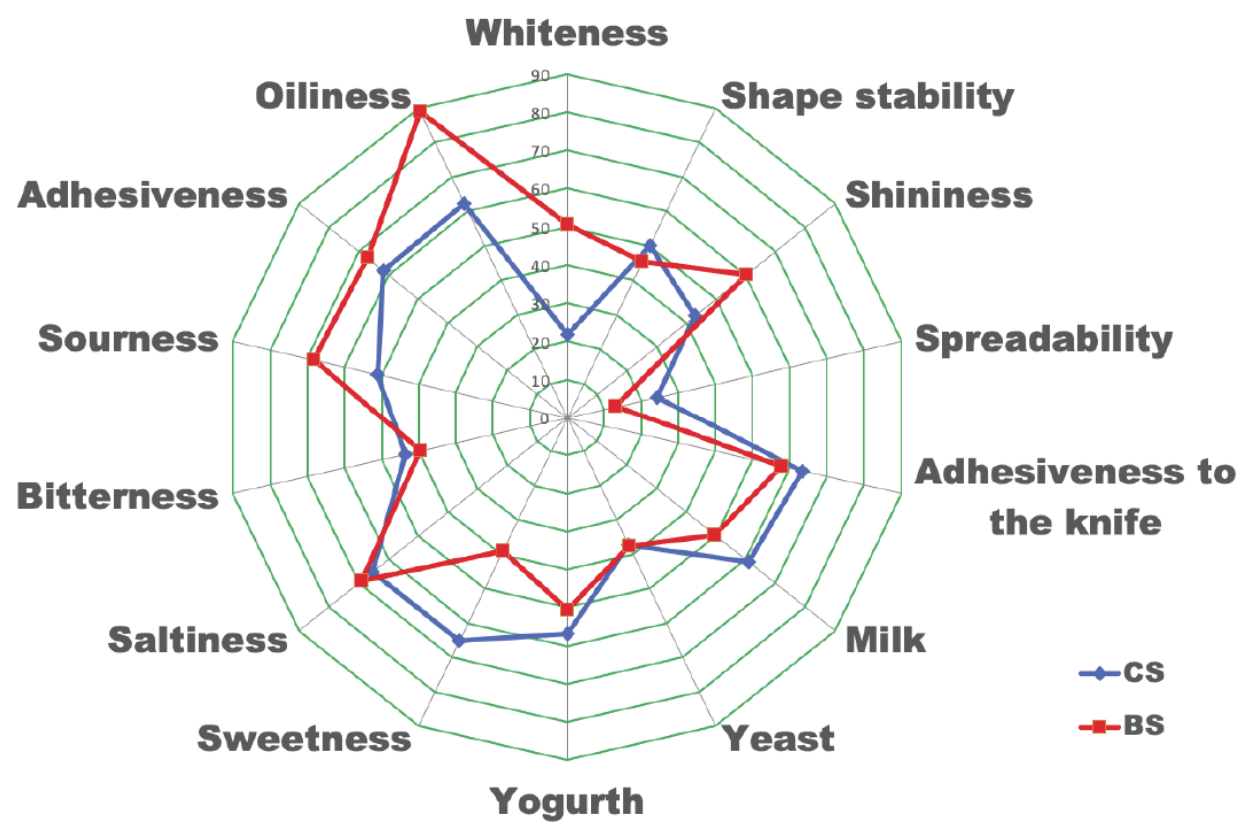

Figure 1: Sensory profile of stracchino cheese: effect of milk type $(C S=$ cow Stracchino cheese; BS = buffalo Stracchino cheese).

Conversely, in terms of odour/flavour attribute intensities, CS was rated higher in milk $(60.84 \pm 3.77$ vs. $49.68 \pm 3.77, P=0.0392)$ and sweetness $(65.26 \pm$ 4.27 vs. 38.96, $P<0.0001)$ than BS. The effect of animal species on the attribute milk may be attributed to the fact that panellists used whole cow milk to define this attribute in the training phase, thus recognizing this odour/flavour at a higher rate in a derived product from cow milk. As to the attribute sweetness, lower acidification of cow milk as compared with buffalo milk may have left a higher amount of lactose in the corresponding cheese, which may explain this result.

Milk type did not affect the overall liking or the liking in terms of taste/flavour, texture, and appearance. In addition, consumers rated both products at scores well above the neutral point $(5=$ neither pleasant nor unpleasant) (Table 2). Therefore, we can assume that consumers liked both products; BS had an eating quality similar to CS and may be well received in the fresh cheese market. In addition, both products exhibited an expected liking (liking expressed only based on the information, without tasting the product) above the liking expressed in blind conditions (tasting the product without any information). In particular, the difference between blind liking - expected liking was significant for CS $(P<0.05)$ and tended to be significant for BS $(P<0.10)$. In both cases, a negative disconfirmation occurred, which means that both products were perceived worse than expected. Our results did not indicate that the Stracchino cheese had a poor eating quality (in blind conditions, both products received a mean score above the central point); rather, they showed that the information on milk type (i.e. the animal species producing the milk) might have an effect on consumer expectations. Generally, for food, including cheese, following a negative disconfirmation, the assimilation model occurs, and the actual liking (tasting the product while also receiving the information) moves in the direction of the expectations [26]. Although in the present experiment, the actual liking was not evaluated due to the lack of samples available. It can be hypothesized that, if the consumers are informed about the fact that the Stracchino cheeses were made by using buffalo milk, the liking of the product may further increase, thus supporting the

Table 2: Liking (Mean $\pm \mathrm{SE}$ ) of Stracchino Cheese as Affected by Milk Type

\begin{tabular}{|c|c|c|c|}
\hline \multirow{2}{*}{ Liking } & \multicolumn{2}{|c|}{ Milk type } & \\
\hline \hline Appearance & $6.80 \pm 0.17$ & $6.58 \pm 0.17$ & NS \\
\hline Taste/Flavour & $6.58 \pm 0.14$ & $6.83 \pm 0.14$ & NS \\
\hline Texture & $6.90 \pm 0.17$ & $6.69 \pm 0.17$ & NS \\
\hline Overall & $6.78 \pm 0.13$ & $6.76 \pm 0.13$ & NS \\
\hline
\end{tabular}

CS = Cow STRACCHINO Cheese; BS = Buffalo Stracchino Cheese. 
introduction of this novel product in the market of fresh cheese. Accordingly, previous studies showed a marked effect of positive information about farming practices and animal welfare on cheese actual liking [27].

Table 3: Liking (Mean \pm SE) Expressed by the Consumer Panel in Two Hedonic Tests

\begin{tabular}{|c|c|c|}
\hline & \multicolumn{2}{|c|}{ Milk type } \\
\hline & CS & BS \\
\hline \hline Blind (B) & $6.78 \pm 0.13$ & $6.76 \pm 0.13$ \\
\hline Expected (E) & $7.07 \pm 0.12$ & $7.02 \pm 0.12$ \\
\hline B - E & $-0.3^{*}$ & $-0.26^{>}$ \\
\hline
\end{tabular}

${ }^{*} \mathrm{P}<0.05 ;{ }^{>} \mathrm{P}<0.10$

Blind = Tasting without Information; Expected = Information without Tasting for Cow Stracchino Cheese (CS) and Buffalo Stracchino Cheese (BS).

\section{CONCLUSION}

The main result emerging from this study is the good eating quality of buffalo Stracchino cheese, as evaluated by the consumer panel, and lack of differences between the Stracchino cheeses obtained from cow and buffalo milk in terms of consumer liking. Which may promote a good positioning of this novel product in the market of fresh cheese. The negative disconfirmation observed for BS suggests that the product was perceived worse than expected moreover an assimilation effect may be anticipated (i.e. actual liking increasing and moving in the direction of the expectations). Additional conclusions to be drawn from this study include the development of a specific frame of reference for the sensory evaluation of buffalo Stracchino cheese and the characterization of this novel product in terms of sensory properties. In particular, due to the physio-metabolic characteristics of the animal species, buffalo Stracchino cheese was whiter and shinier, which may also favour the product's image in terms of freshness. Finally, buffalo Stracchino cheese was characterized by higher intensities of the attributes oiliness and sourness, possibly due to the chemical composition of buffalo milk.

\section{REFERENCES}

[1] Food and Agriculture Organization of the United Nations. FAOSTAT Statistical Database, Rome 2020.

[2] Zicarelli L. Current trends in buffalo milk production. J Buff Sci 2020; 9: 121-132.

https://doi.org/10.6000/1927-520X.2020.09.14
[3] Creamer LK, Pearce LE, Hill JP, Boland MJ. Milk and Dairy Products in the 21st century prepared for the 50th anniversary of the Journal of Agricultural and Food Chemistry. J Agric Food Chem 2002; 50: 7187-7193. https://doi.org/10.1021/jf020711b

[4] Zicarelli L. Influence of seasonality on buffalo production. In: Precisse GA, Ed. The Buffalo (Bubalus bubalis). Production and research. Bentham Science Publishers, UAE 2017; pp. 196-224.

https://doi.org/10.2174/9781681084176117010011

[5] Braghieri A, Zotta T, Morone G, Piazzolla N, Majlesi M, Napolitano F. Starter cultures and preservation liquids modulate consumer liking and shelf life of Mozzarella cheese. Intl Dairy J 2018; 85: 254-262. https://doi.org/10.1016/j.idairyj.2018.06.013

[6] Lappalainen R, Kearney J, Gibney M. A pan EU survey of consumer attitudes to food, nutrition and health: An overview. Food Qual Prefer 1998; 9: 467-478.

https://doi.org/10.1016/S0950-3293(98)00018-4

[7] Tidona F, Francolino S, Ghiglietti R, Locci F, Brusa G, Alinovi M, Mucchetti G, Giraffa G. Application of recombined milk to produce Crescenza-type cheese in laboratory-scale cheesemaking: implications on technology and sensory properties. Foods 2020; 9(7): 928. https://doi.org/10.3390/foods9070928

[8] Braghieri A, Piazzolla N, Romaniello A, Paladino F, Ricciardi A, Napolitano F. Effect of adjuncts on sensory properties and consumer liking of Scamorza cheese. J Dairy Sci 2015; 98: 1479-1491.

https://doi.org/10.3168/jds.2014-8555

[9] Lawless HT, Heymann H. Sensory evaluation of food: Principles and practices. Chapman and Hall, Springer Publishing, New York, NY 2010.

[10] Napolitano F, Castellini C, Naspetti S, Piasentier E, Girolami A, Braghieri A. Consumer preference for chicken breast may be more affected by information on organic production than by-product sensory properties. Poult Sci 2013; 92: 820-826. https://doi.org/10.3382/ps.2012-02633

[11] ISO (International Organization of Standardization). Sensory analysis e general guidelines for the selection, training and monitoring of selected assessors and expert sensory assessors. ISO 8586. 2012; ISO, Geneva, Switzerland.

[12] Albenzio $M$, Santillo A, Caroprese M, Braghieri A, Sevi A, Napolitano F. Composition and sensory profiling of probiotic Scamorza ewe milk cheese. J Dairy Sci 2013; 96: 27922800.

https://doi.org/10.3168/jds.2012-6273

[13] Rumeau C, Nguyen DT, Jankowsk R. How to assess

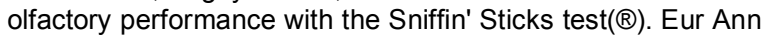
Otorhinolaryngol Head Neck Dis 2016; 133: 203-206. https://doi.org/10.1016/j.anorl.2015.08.004

[14] Societa Italiana di Scienze Sensorali. Atlante Sensoriale dei prodoti di origine animale Tecniche Nuove - Milano 2012.

[15] Stone H, Sidel JL. Sensory Evaluation Practices. 3rd ed. Elsevier Academic Press, London, UK 2004.

[16] ISO (International Organization of Standardization). Sensory analysis: General guidance for the design of test rooms - ISO 8589. ISO, Geneva, Switzerland 2007.

[17] Hersleth $M$, Ueland $O$, Allain H, Naes T. Consumer acceptance of cheese, influence of different testing conditions. Food Qual Prefer 2005; 16: 103-110. https://doi.org/10.1016/j.foodqual.2004.02.009

[18] Markey O, Souroullas K, Fagan CC, Kliem KE, Vasilopoulou D, Jackson KG, Methven L. Consumer acceptance of dairy products with a saturated fatty acid reduced monounsaturated fatty acid-enriched content. J Dairy Sci 2017; 100: 7953-7966.

https://doi.org/10.3168/jds.2016-12057 
[19] Peryam DR, Pilgrim FJ. Hedonic scale method of measuring food preferences. Food Technol 1957; 11(Suppl): 9-14.

[20] SAS. SAS/STAT user's guide (version 6), 4th ed. Statistical Analysis Systems Institute 1990; Cary, NC, USA.

[21] Garau V, Manis C, Scano P. Caboni P. Compositional characteristics of mediterranean buffalo milk and whey. Dairy 2021; 2: 469-488.

[22] Cheng N, Barbano DM, Drake MA. Effect of pasteurization and fat, protein, casein to serum protein ratio, and milk temperature on milk beverage color and viscosity. J Dairy Sci 2019; 102: 2022-2043. https://doi.org/10.3168/jds.2018-15739

[23] Nozière P, Graulet B, Lucas A, Martin B, Grolier P, Doreau M. Carotenoids for ruminants: From forages to dairy products. Anim Feed Sci Technol 2006; 131: 418-450. https://doi.org/10.1016/j.anifeedsci.2006.06.018
[24] Fundora O, Gonzalez ME, Lezcano O, Montejo A, Pompa N, Enriquez AV. A comparative study of milk composition and stability of Murrah river buffaloes and Holstein cows grazing star grass. Cuban J Agric Sci 2001; 35: 219-222.

[25] Ahmad S, Gaucher I, Rousseau F, Beaucher E, Piot M, Grongnet JF, Gaucheron F. Effects of acidification on Physico-chemical characteristics of buffalo milk: A comparison with cow's milk. Food Chem 2008; 106: 11-17. https://doi.org/10.1016/j.foodchem.2007.04.021

[26] Napolitano F, Girolami A, Braghieri A. Consumer liking and willingness to pay high welfare animal-based products. Trends Food Sci Technol 2010a; 21: 537-543. https://doi.org/10.1016/j.tifs.2010.07.012

[27] Napolitano F, Braghieri A, Piasentier E, Favotto S, Naspetti $S$, Zanoli R. Cheese liking and consumer willingness to pay as affected by information about organic production. J Dairy Res 2010b; 77: 273-279. https://doi.org/10.1017/S0022029910000130

https://doi.org/10.6000/1927-520X.2021.10.12

(C) 2021 Di Cairano et al.; Licensee Lifescience Global.

This is an open access article licensed under the terms of the Creative Commons Attribution License (http://creativecommons.org/licenses/by/4.0/) which permits unrestricted use, distribution and reproduction in any medium, provided the work is properly cited. 